\title{
DOUBLE TAXATION CONSIDERATIONS WITH REFERENCE TO THE AVOIDANCE OF DOUBLE TAXATION OF VALUE ADDED TAX BETWEEN THE REPUBLIC OF SERBIA AND KOSOVO UN 1244
}

\author{
SPALEVIC Zaklina ${ }^{1}$, RAPAJIC Milan ${ }^{2}$, VELICKOVIC Dragisa ${ }^{3}$ \\ ${ }^{1}$ Faculty of Tourism and Hospitality Management, Singidunum University Belgrade \\ ${ }^{2}$ Faculty of Law, University of Kragujevac \\ ${ }^{3}$ Faculty of Business, Singidunum University Belgrade \\ E-mails:zspalevic@singidunum.ac.rs,mrapajic@jura.kg.ac.rs,dvelickovic@singidunum.ac.rs
}

\begin{abstract}
Tax is the most important type of public revenue. Taxes are necessary for the functioning of the state. It is difficult to imagine the state as a legal entity, without taxes. Most of the funds for financing public expenditures were obtained through taxation. The phenomenon of double taxation occurs when several sovereign countries claim the right to tax the same taxpayer for an identical period, which leads to a more severe form of taxation to the detriment of the taxpayer. The aim of this paper is to present the way of treating the problem of double taxation with special reference to the methods and measures of eliminating double taxation. The authors also point to certain aspects of the problem of double taxation in Kosovo UN 1244
\end{abstract}

Keywords: tax; double taxation; measures to combat double taxation; tax object; taxpayer; avoidance of double taxation of value added tax; Kosovo UN 1244;

JEL:O10

DOI: $10.5937 /$ intrev2102185S

UDC: 336.227.1/.2(497.115)

COBISS.SR-ID 43527177 


\section{DOUBLE TAXATION}

The world economy is based on global trade, international trade in goods and factors of production. Foreign direct investments generate income for domestic and foreign entities. Every state, of course, intends to tax your income. Tax is the revenue of the state that it collects on the basis of power (forced giving) from the subjects under its sovereignty, without direct compensation, in order to cover public expenditures. "If the same taxpayer is taxed more than once, then there will be double legal taxation."[10] Double taxation is an obstacle to the movement of capital and investment from one territorial unit to another. The consequences of international double taxation are unfavorable from an economic and fair point of view. "People in this situation are discriminated against in relation to other people whose income or residence does not have an international component.[5] Double taxation directly increases the cost of capital movements. Thanks to double taxation, the economic position of taxpayers who are closed within the borders can be far more favorable. national economies in relation to those engaged in international business. "[3]

Double taxation is a situation in legal life, when the same person and in connection with the same subject of taxation is taxed with the same or similar taxes, for the same period by several tax authorities, which are of the same rank[6]. "In other words, double taxation exists when the same tax event is regulated in two different tax laws as a fact that gives rise to a tax liability."[9] There are internal and international double taxation, depending on who are the bearers of the conflicting tax jurisdictions. When there is a conflict between the members of a federal state - a republic, a state (what is the name of federal units in the Russian Federation, ie states in the United States) or provincial (example of the Federal Republic of Germany), or local self-government units within one state, then on internal double taxation.[7] "International double taxation exists when, for the same subject of taxation, the same or a similar tax is levied on the same person for the same period by two or more States." Therefore, for double taxation, in addition to the existence of at least two tax authorities of the same rank, the identity of the following elements is required: the taxpayer, the subject of taxation, the tax and the period in which the taxation is performed.[4]

The identity of the object of taxation or tax object means the equality of objective facts, the appearance of which gives rise to a tax liability.[11] Examples of these facts are: the physical existence of the taxpayer, the existence of rights, realized income or income or turnover of products or services. "For the identity of the subject of taxation, it is not necessary that the legal definition of the object of taxation or the procedure for determining the tax base be the same in both countries."[3] "It is not always easy to determine the identity of the taxes introduced by two different tax authorities. In order to be double taxed, it is necessary for the taxes to be similar, that is, to be basically the same."[10] The criterion on the basis of which the identity of the tax is determined does not always have to be the legal definition or name, but the economic character of the subject of taxation.[12]

When taxation refers to the time in which the tax liability arose, then it can be about the identity of the taxation period. More precisely, if the tax liability arises when a tax event occurs that can be subsumed under the legal description of the tax factual situation, then double taxation means that this tax event is normatively regulated in at least two tax regulations. It is a matter of double taxation when the same tax event is regulated in two different tax laws as a fact that leads to the occurrence of a tax liability.[13]

Phenomena that are similar but also have significant differences should be distinguished from double taxation. With double taxation, the points of contact are: additional taxation, tax accumulation and economic double taxation. The difference between double taxation and additional taxation, for example, is that double taxation is the taxation of the same person in connection with the same subject of taxation, the same or similar taxes for the same period by several tax authorities of the same rank. One tax authority is superior to another (lower) tax authority when it comes to taxation. When the same taxpayer has the obligation to pay several different taxes on the same tax object in the same time interval, with different manifestations of his tax power, then it is a matter of accumulating taxes.[14]

"Economic double taxation exists when two legally different but economically related taxpayers are taxed with the same tax, in the same time period, in relation to the same subject of taxation. Thus, for example, there will be economic double taxation when the owner and usufructuary of the same real estate."[9] " Economic double taxation occurs when it is prescribed that a company should pay tax on its profits, and its shareholders should additionally pay tax on dividends paid from that taxable profit."[15] It 
is easily distinguished from legal double taxation, since in economic there are two taxpayers, who have a special legal personality, but there is an economic link between them. This type of double taxation can be internal, within one state, or international, between two states.

Double taxation arises as a result of conflicts of tax laws. The conflict of tax jurisdictions arises because the principles that would limit the sovereignty of the state in the tax sphere are not founded in international public law. The principle of extraterritoriality is a legitimate exception, on which tax and other fiscal privileges are based, and they apply to the staff of diplomatic and consular missions of foreign countries in the receiving country. Which decisive facts will be taken as important for the tax jurisdiction is directly related to how the state regulates its national interest in the field of tax law. The tax jurisdiction of the state is conditioned by the circumstance that there should be a specific connection between the state and the taxpayer and it is called a decisive fact or principle for determining the tax jurisdiction. Thus, "a state imposes a tax claim only on persons who are in some way subject to its territorial sovereignty on the basis of certain decisive tax facts. The determination of different decisive facts between different states leads to international double taxation. Conflict of tax jurisdictions of sovereign states is resolved by applying unilateral or bilateral measures ".[3]

The decisive facts on the basis of which the state establishes tax jurisdiction are: 1. the principle of citizenship; 2. residency principle; 3 . source principle. The principle of citizenship means that the state has the right to tax all persons who are its citizens, regardless of where they earn income or where they own property. "The United States establishes such jurisdiction over its citizens and companies established in the United States, regardless of where the income originated. Business profits made by a U.S. corporation in Italy are taxable in the United States (and normally in Italy). a citizen who has a residence in Switzerland and comes from employment in Switzerland is taxable in the United States (and also in Switzerland). "[2] The principle of citizenship causes the citizens of one country to be at a disadvantage compared to non-citizens when both earn income or have property in that country. The principle of citizenship, as a decisive fact, no longer has the significance it had in the past. In addition to the United States, only the Philippines still takes citizenship as a decisive fact in establishing tax jurisdiction. The principle of citizenship is increasingly giving way to another decisive fact, residency.

Residence is the permanent or temporary physical presence of a person in a certain territory. This principle implies that a natural person is taxed in the country where he resides for a certain period, regardless of the source of income. "Tax residency is usually established for a particular fiscal year, but the length of stay is important on the basis of which it is determined whether a person was a resident of a state in the prescribed period of the observed fiscal year."[3]

The source principle refers to the territory in which the real estate is located, a permanent business unit or a permanent base in which professional activity is performed, on which funds are used from which dividends and royalties from copyright and industrial property rights are paid, ie where resident debtor who pays interest. According to the decisive fact of the source, "only the source country should tax dividends, interest and royalties originating from its territory, as well as business profits made by a non-resident company."[15]

\section{METHODS OF ELIMITING DOUBLE TAXATION}

The elimination of double taxation is done through methods implemented by the state of residence, in those situations when the conflict rules are not of absolute importance, ie when a subject of taxation can be taxed by both the country of residence and the country of origin. In that case, the conflict rules cannot prevent double taxation, so it is necessary for the country of residence to take additional measures.[17] These additional measures are: the exemption method and the credit method. With the exemption method (which has two forms in the taxation of personal income tax and with other progressive taxes: the full exemption method and the progressive exemption method), the state does not tax a certain income, ie certain property items that can be taxed only in another state.[18] A variant of the method of excluding the so-called full exemption (which is rarely used as a method) means that the state of residence does not take into account income or property that is exempt from taxation when determining the progressive tax rate that will be applied to the rest of the income, ie property. It should be borne in mind that the application of this method does not take into account part of the income, ie property that is excluded in the country of origin. [19]In the case of the progressive exemption method, the country of residence exempts from taxation the income earned in the country of source, ie property located in the country of source in order to eliminate privileges based on the effect of progressive tax rates. Excluded income or assets are taken into account when applying a progressive tax rate to the rest of the income or assets.[20] 
By applying the credit method (which originated in the Anglo-American tax system), the state deducts the tax paid in the source country on certain parts of the taxpayer's income or property from the tax it determines on world income, ie on the world property of its resident. There are several types of loans, depending on the size and type of double taxation that needs to be eliminated. The full credit method and the ordinary credit method are types that occur depending on the size of the loan. The procedure by which the tax paid in the country of origin is deducted in full from the tax imposed by the country of residence, it does not matter whether the amount of tax paid abroad is greater than that part of the tax which could be attributed to the income in the country of residence. is realized or the property is owned abroad, is a method of full credit. The ordinary credit method (which is in practice less common than the full credit method) is the procedure by which a tax paid in the country of origin is recognized as a credit at the expense of the tax determined in the country of residence, but only up to the amount in the country of residence. tax rates, could be attributed to income or assets earned abroad.[21]

If the type of double taxation that is eliminated is taken into account, two methods of tax credit can be applied: the method of direct tax credit and the method of indirect tax credit. Elimination of double legal taxation is done by applying the method of direct tax credit. On the other hand, the elimination of double economic taxation is regulated by applying the method of indirect tax credit.[29]

\section{CONVENTION FOR THE AVOIDANCE OF DOUBLE TAXATION}

The methodology for avoiding international double taxation is determined by two instruments: domestic regulations and international agreements. Adequate implementation of international agreements in the tax system enables taxpayers to make large tax savings.

Conventions are interstate agreements or treaties and serve to avoid international double taxation. They are subject to the regulations of the state or territorial unit on entry into force (upon ratification), as well as other international agreements. "The question of the relationship between international conventions on the avoidance of double taxation and national law is raised, ie the question of the place of international conventions in the hierarchy of national sources of law. Two solutions are possible in this regard. First, international conventions take precedence over domestic legislation. second, international treaties have the same rank as national laws. "[9]

It is possible that, based on the conflict-of-law rules in the convention, a state has the exclusive right to tax in relation to a particular subject of taxation. The basic goal of the convention on the avoidance of double taxation through such conflict-of-law rules was then achieved, so that additional procedures have no purpose. However, when a subject of taxation may be taxed both in the country of residence and in the country of origin, then the conflict rules cannot prevent double taxation. It is necessary for the state to be able to apply some of the methods to eliminate double taxation.[31] International conventions on the avoidance of double taxation have advantages over domestic measures to eliminate double taxation, but also certain disadvantages. "The advantages of international measures are reflected in the fact that: 1) they ensure uniformity in relations between different countries, improve investment conditions, as they ensure the stability of the tax regime in the country where capital is imported, and 3) contribute to more efficient fight against tax evasion." The disadvantages of international conventions on the avoidance of double taxation in relation to unilateral measures are the following: 1) the process of concluding international conventions usually takes a long time, 2) agreement on concluding a convention can be reached if differences in national tax legislation are not large, 3 ) international measures restrict the state to completely autonomously creates its tax policy and the like. "[9]

International conventions can be bilateral or multilateral. Most often, they are bilateral conventions concluded between two countries. "Multilateral conventions for the avoidance of double taxation constitute an agreement between at least three Contracting States. They establish in a uniform manner the principles which delimit the tax jurisdictions of the Contracting States and regulate methods for preventing or eliminating double taxation."[22] Multilateral conventions have the advantage that a number of states agree to remove double taxation from their tax systems and because they contribute to the creation of unified rules in this area of tax matters. However, the number of multilateral conventions is small and this is proof that different tax systems are still easier to harmonize on the basis of bilateral conventions. 


\section{AVOIDANCE OF DOUBLE TAXATION OF VALUE ADDED TAX BETWEEN THE REPUBLIC OF SERBIA AND KOSOVO UN 1244}

In 2005, the Government of the Republic of Serbia made a unilateral decision to abolish VAT on goods distributed in Kosovo and Metohija. The exchange between Serbia without Kosovo and Kosovo is carried out freely on the basis of the CEFTA agreement signed on behalf of Kosovo by UNMIK, which, respecting the sovereignty of Serbia, did not charge customs duties on goods of Serbian origin. As VAT is not paid on goods shipped from Serbia that are distributed in Kosovo, but only the UNMIK tax, space is open for various types of abuse. Goods from Serbia entered Kosovo with a so-called certified sheet, which was stamped at the administrative border with which the goods were exempt from VAT. The VAT exemption for goods entering Kosovo is justified by EU standards which stipulate that taxation is done according to the place of consumption. This means that, even if Serbia considers Kosovo and Metohija part of its territory, goods shipped there are exempt from VAT in order to avoid double taxation, given that these goods are taxed by Kosovo's temporary institutions. In that way, the goods placed on the territory of Kosovo were given the status of exported goods, exports. In fact, these goods have the same status as the goods that are exported, sold to any other country whose sovereignty is recognized by the Republic of Serbia. Pursuant to the decree of 14 December 2013, the evidence that the goods were shipped to Kosovo are considered to be: a single document issued in accordance with applicable regulations containing a certificate that the goods withdrew from the territory of the Republic of Serbia to the territory of AP Kosovo and Metohija; excerpt from the business account of the VAT payer that the transfer of funds from the business account of the recipient of the goods to the business account of the VAT payer - the supplier of the goods has been made for the supply of goods.[32]

The novelty is that instead of the Evidence Document (certified sheet), a single document (JCI) issued in accordance with customs regulations is now used as evidence. In that way, double taxation is avoided, and such a commodity regime is valid for the entire territory of Kosovo during the period of validity of the UN Security Council Resolution no. 1244. Products imported into Kosovo from third countries, if cleared through customs in Serbia without Kosovo, were subject to a customs duty of 10\%, while imported goods from third countries that transited through Serbia without Kosovo and were not cleared through customs. , appropriate customs duties were charged according to the UNMIK tariff. VAT is calculated and paid on the supply of goods from Kosovo to the territory of the Republic of Serbia in accordance with the law[33].

When it comes to the movement of goods from Kosovo to Serbia, the Government of Serbia does not intend to withdraw the decision which from December 3, 2008 prohibits the entry and transit of products from Kosovo in which the accompanying documentation mentions Kosovo Customs instead of UNMIK customs. At the same time, no one officially wants to comment on the decision of the temporary authorities in Pristina to retaliate with the same measure, which is also one of the major disagreements in the negotiations between Belgrade and Pristina in Brussels. Serbia without Kosovo, by the way, delivers 15 times more goods to the territory of Kosovo than it buys from Kosovo. According to the data of the Serbian Customs Administration, the total registered turnover of Serbia without Kosovo and Kosovo in 2015 amounted to 199.7 million dollars. A total of 189.7 million dollars of goods produced in Serbia without Kosovo were sold on the territory of Kosovo. That amount, by the way, represents 2.1 percent of the total export of Serbia. In the same period, goods worth 10.04 million dollars were placed in Serbia from Kosovo, which is 0.06 percent of the total Serbian imports.

Serbian producers traditionally sell goods in Kosovo. There are fears that, due to political relations, this market could be taken over by companies from other countries.

\section{CONCLUSION}

The issue of double taxation is topical at the international level. This is a consequence of the permanent process of exchanging goods and services. There are also double antagonistic interests. On the one hand, states are trying to expand their tax jurisdiction. On the other hand, individuals and legal entities have an interest in reducing expenditures. For individual individuals and legal entities living in two or more countries, the main interest is to reduce expenditures and avoid double taxation. In the positive law of Serbia, the avoidance of double taxation is regulated so that there are over thirty treaties (which have been ratified and implemented in national legislation) that regulate this area. In principle, it is crucial for every 
country, (including Serbia) to solve the problem of double taxation. One of the most appropriate solutions is to conclude international agreements with countries with which there is the best economic cooperation. However, the solution that Serbia concludes agreements on avoiding double taxation with countries that are not its most important economic partners is also useful. Such cooperation leads to the improvement of economic and financial relations at the international level.

Since declaring disputed independence, Kosovo has signed a small number of double taxation treaties. The number of agreements signed is in great disproportion even with the number of countries that have recognized Kosovo's independence. It is clear that the territory that does not have full state capacity has a limited scope for concluding international agreements, which causes great damage to the process of attracting foreign direct investments. Thus, the development performance of this economic territory is limited.

\section{REFERENCES}

[1] Kesner-Škreb M.(2005): Dvostruko oporezivanje, Finansijska teorija i praksa, 4, Zagreb, 443

[2] Kulić M., (2010) : Javne finansije, Megatrend univerzitet, Beograd, 128

[3] Popović D. (2021): Poresko pravo - opšti deo, Beograd, 335-336

[4] Popović D., Kostić S. (2009): Ugovori Srbije o izbegavanju dvostrukog oporezivanja, Pravni okvir i tumačenje, Beograd, 4

[5] Nazneen A., Wei X., End of double taxation: Is the policy better when announced?, Journal of Policy Modeling, Vol. 35, Iss. 6, pp. 928-942, 2013.

[6] Marius E. R., International Double Taxation, Procedia - Social and Behavioral Sciences, Vol. 62, pp. 403-407, 2012.

[7] Anh D. P., Ha P., Kim C. L., Double Taxation Treaties as a Catalyst for Trade Developments: A Comparative Study of Vietnam's Relations with ASEAN and EU Member States, Journal of Risk and Financial Management, Volume 12, No. 4, 172, 2019. https://doi.org/10.3390/jrfm12040172

[8] Aart G. (2016) Optimal Nonlinear Taxation: The Dual Approach, Working Paper of the Max Planck Institute for Tax Law and Public Finance No. 2016-2, Available at SSRN: https://ssrn.com/abstract=2726545 or http://dx.doi.org/10.2139/ssrn.2726545

[9] Ángela, C.M., and Julio, L.L., (2019) The effect of double taxation treaties and territorial tax systems on foreign direct investment: Evidence for Spain, Economics: The Open-Access, Open-Assessment EJournal [online], available: EconStor: The effect of double taxation treaties and territorial tax systems on foreign direct investment: Evidence for Spain [accessed 29 January 2021].

[10] Arnaldur S. K. (2013) Redistributive Effects in a Dual Income Tax System, JSTOR, 69 (2), p. 148-166

[11] Kunka P., Andrzej S., Martin Z., On the relevance of double tax treaties, International Tax and Public Finance, Vol. 27, pp. 575-605, 2020.

[12] Kunka P., Withholding tax rates on dividends: symmetries versus asymmetries or single- versus multirated double tax treaties, International Tax and Public Finance, Vol. 28, pp. 890-940, 2021.

[13] Kunka P., Andrzej S., Martin Z.,Bilateral Tax Competition and Regional Spillovers in Tax Treaty Formation, WU International Taxation Research Paper. No. 2020-04, 2020. http://dx.doi.org/10.2139/ssrn.3567791

[14] Paul L. B., An Analysis of Double Taxation Treaties and their Effect on Foreign Direct Investment, International Journal of the Economics of Business, Vol. 29, Iss. 3, pp. 341-347, 2014.

[15] Fabian, B., and Eric, N. (2012) Competing for Scarce Foreign Capital: Spatial Dependence in the Diffusion of Double Taxation Treaties, International Studies Quarterly, 56 (4), p. 645-660.

[16] Jukka, P. and Håkan, S. (2011) Income Shifting within a Dual Income Tax System: Evidence from the Finnish Tax Reform of 199, The Scandinavian Journal of Economics, 131 (1), p. 120-144.

[17] Julia B., Martin Z., An Economic Perspective on Double Tax Treaties with(in) Developing Countries, World Tax Journal, Vol.6, pp. 242-281, 2014. 
[18] Scott D. D., Bradley P.L., Kevin S.M., Douglas A.S., The effect of tax and nontax country characteristics on the global equity supply chains of U.S. multinationals, Journal of Accounting and Economics, Vol. 59, Iss. 2-3, pp/ 182-202, 2015.

[19] Céline A., Dhammika D., Tax sparing agreements, territorial tax reforms, and foreign direct investment, Journal of Public Economics, Vol. 169, pp. 89-108, 2019.

[20] Sunghoon H., Tax treaties and foreign direct investment: a network approach, International Tax and Public Finance, Vol. 25, pp. 1277-1320, 2018.

[21] Mário M., Carlos P., Tax-Treaty Effects on Foreign Investment: Evidence from European Multinationals, Finanz Archiv: Public Finance Analysis, Vol. 70, No. 4, pp. 527-555, 2014.

[22] Kalaš, B., Mirović, V., Milenković, N. (2018). The Relationship Between Taxes and Economic Growth: Evidence from Serbia and Croatia. The European Journal of Applied Economics, 15(2), 17 28. doi:10.5937/EJAE15-18056

[23] Milošević G. (2013): Teorija i praksa finansijskog prava, Beograd, 120

[24] Nazneen, A. and Wei, X. (2013) End of double taxation: Is the policy better when announced? Journal of Policy Modeling, 35 (6), p. 928-942

[25] Hui, D., and Steven A. H. (2013) The impact of double taxation on small firms' cash holdings, Applied Financial Economics, p. 1349-1359

[26] Paul, L. B. (2014) An Analysis of Double Taxation Treaties and their Effect on Foreign Direct Investment, International Journal of the Economics of Business, 21 (3), p. 341-377

[27] Richard, M.B., and Eric, M.Z. (2011) Dual Income Taxation: A promising Path to Tax Reform for Developing Countrie, World Development, 39 (10), p. 1691-1703

[28] Ryo, I. (2020) Corporate structural change for tax avoidance: British multinational enterprises and international double taxation between the First and Second World Wars, Business History, p. 1-24

[29] Guttorm S., Secrecy jurisdictions, International Tax and Public Finance, Vol. 23, pp. 168-189, 2016.

[30] Peter H., The Role of Double Tax Conventions in International Tax Law, Journal of Interdisciplinary Rresearch, Vol. 3, Iss. 1, pp. 50-53, 2013.

[31] Department of Economic and Social Affairs, Model Double Taxation Convention between Developed and Developing Countries, United Nations, New York, 2017. https://www.un.org/esa/ffd/wpcontent/uploads/2018/05/MDT_2017.pdf

[32] https://www.transparency.org/en/news/corruption-perceptions-index-2017

[33] Raičević Božidar (2004): Porez na dodatu vrednost - teorijski i praktični aspekt, Ekonomski anali, Beograd, 2-5.

Article history:

Received 11 March 2021

Accepted 12 July 2021 